Article

\title{
Assessment of Ecological Vulnerability under Oil Spill Stress
}

\section{Ling Cai, Li Yan, Jialin Ni * and Cui Wang}

Third Institute of Oceanography of State Oceanic Administration, Xiamen 361005, China;

E-Mails: cailing@tio.org.cn (L.C.); yanli@tio.org.cn (L.Y.); wangcui@tio.org.cn (C.W.)

* Author to whom correspondence should be addressed; E-Mail: nijialin@tio.org.cn;

Tel./Fax: +86-592-2195-335.

Academic Editor: Xinyue Ye

Received: 16 July 2015 / Accepted: 31 August 2015 / Published: 24 September 2015

\begin{abstract}
Using the constituent elements of vulnerability, an evaluation index system for the ecological vulnerability of coastal areas under oil spill stress is established based on "Sensitivity-Adaptive Capacity-Exposure". After selecting a gulf in China as the main case study in this work, the cluster analysis and reference method were applied in grading and value assigning for all indexes. In addition, the analytic hierarchy process and expert evaluation method were used to determine the index weighting. Finally, a comprehensive evaluation method was adopted in the evaluation studies on the ecological vulnerability of the gulf coastal zone under oil spill stress. Results show the differences between the gulf area and areas that belong to different ecologically-vulnerable areas under oil spill stress.
\end{abstract}

Keywords: oil spill stress; coastal zone; ecological vulnerability assessment

\section{Introduction}

Owing to the rapid development of offshore oil exploitation and transportation industries, the number of oil tankers on the sea continues to increase, which heightens the potential risks of offshore oil spill accidents. An offshore oil spill accident will cause serious disasters to the ecosystem in the coastal areas. One example is the spill caused by the accident involving the tanker Exxon Valdez in 1989, which released about 36,000 tons of crude oil in Alaska, affecting $1500 \mathrm{~km}$ of coastline [1]; the spilled oil seriously affects coastal wild life and deeply impacts habitats and socio-economic activities. As the transitional zone between the sea and the land, the coastal zone has a rich and most valuable biosphere environment. 
To help the emergency decision makers of oil spill accidents identify the hotspots of the coastal zone rapidly, develop the oil spill clean-up strategies scientifically, and reduce the losses caused by oil spill accidents, as well as the ecological damage during the accident clean-up process, scholars and experts have carried out research on the ecological vulnerability of the coastal zone under oil spill stress. In 1978, Miles O. Hayes and Erich R. Gundlach [2] studied the coastal vulnerability evaluation under oil spill stress. Subsequently, studies on vulnerability evaluation of coastal zones under oil spill stress have been conducted in New Zealand, Israel, Australia, Spain, and Brazil, among others [3-7]. However, past studies focused on the qualitative evaluation, which emphasized the lack of quantitative studies.

In recent years, the number of quantitative studies on coastal vulnerability evaluation under oil spill stress has gradually increased. Castanedo [8] studied the Cantabrian coastal zone and divided the coastal zones into 200-meter evaluation units. Three different calculation methods, namely, worst-case performance value, mean index value, and comprehensive index value were used to calculate the vulnerability of coastal zones. In 2011, Milena Marilia et al. [9] divided the coastal vulnerability under oil spill stress into socio-economic vulnerability and natural vulnerability, superimposed the scores of each indicator, and obtained the vulnerability distribution of coastal areas. In the vulnerability evaluation under oil spill stress on the national scale, Nuanchan Singkran [10] took passing density, traffic volume, wharf distribution, and other factors into consideration. In 2013, Freydoon et al. [11] assessed the possible coastal zones that oil spill incidents may endanger and selected physical indicators, biological indicators, socio-economic indicators, and so on, along the coast to construct the vulnerability assessment index system. The researchers also constructed a fuzzy multi-index decision model based on fuzzy assemblage theory, analysis of hierarchy-based structure, and APH theory and used the GIS system to map the distribution of oil spill sensitivity in the coastal zone of Northern Iranian Mazandaran. Tiago M. Alves [12,13] combined bathymetric, geomorphological, geological data, and oil spill predictions to model the impact of oil spills in two accident scenarios from offshore Crete, Eastern Mediterranean in 2014.

Although there is significant research on ecological vulnerability assessment of coastal zones under oil spill scenarios, there were no mature and suitable theoretical systems to guide the authors, as it is easy to confuse vulnerability and sensitivity, and the evaluation methods in other studies were different. In this study, the authors constructed an assessment system, suitable for oil spill-disturbed ecosystems, based on the constituent elements of vulnerability. Combined with the results of numerical simulation of an oil spill, a distribution of the coastal zone's vulnerability under oil spill stress was delineated.

\section{Methods}

\subsection{Definition of Vulnerability}

Ecological vulnerability is used to describe a property of a specific system that is exposed to the external or internal disturbances, and whose structure and functions easily change due to its sensitivity to the disturbances and lack of adaptive capability [14,15]. Vulnerability is a measure of the possible damage or degree of degradation of the ecosystem [16]. Researchers generally believe that vulnerability is composed of three elements, namely, exposure, sensitivity, and adaptive capability [17]. Exposure reflects the degree to which the ecosystem becomes easily vulnerable to environmental and social 
stresses. The value of vulnerability decides the potential degree of damage of the system under the influence of accidents [14]. Sensitivity reflects the degree of positive or negative impact to which the exposure unit becomes easily vulnerable to the stress. Sensitivity is the multi-dimensional dose-response relationship between the stress and the consequences [15]. Adaptive capability reflects the capacity of the system to respond and cope with the external stress or internal disturbance and to recover from the loss caused by a disaster [17]. Generally, the increase in exposure and sensitivity intensifies the vulnerability of the exposure unit and the complexity of the relationship between adaptive capability and vulnerability because such a relationship is not a simple linear one [18]. The interaction between the environment and the social drive decides the exposure and sensitivity of the system. Different social, economic, political, scientific, technological, and cultural conditions change the adaptive capability of the exposure unit. Thus, the systematic vulnerability evaluation method that consists of exposure, sensitivity, and adaptive capability was applied in the present research to realize a metrizable vulnerability evaluation.

In this study, a typical gulf in China was selected according to the constituent elements affecting the vulnerability of the coastal ecosystem, namely, sensitivity and adaptive capability of the system against stress and exposure of the system relative to stress. Consequently, a vulnerability evaluation system for the ecosystem was constructed.

\subsection{Study Area}

Dongshan Bay is located in the southeast coast of Fujian Province of China (Figure 1), with geographical coordinates of $23^{\circ} 43^{\prime} 12^{\prime \prime} \mathrm{N}-23^{\circ} 55^{\prime} 10^{\prime \prime} \mathrm{N}, 17^{\circ} 26^{\prime} 30^{\prime \prime} \mathrm{E}-117^{\circ} 36^{\prime} 48^{\prime \prime} \mathrm{E}$. The plan to convert the bay into a petrochemical harbor will increase the number of oil shipping tankers, which will consequently increase the risks of oil spill accidents.

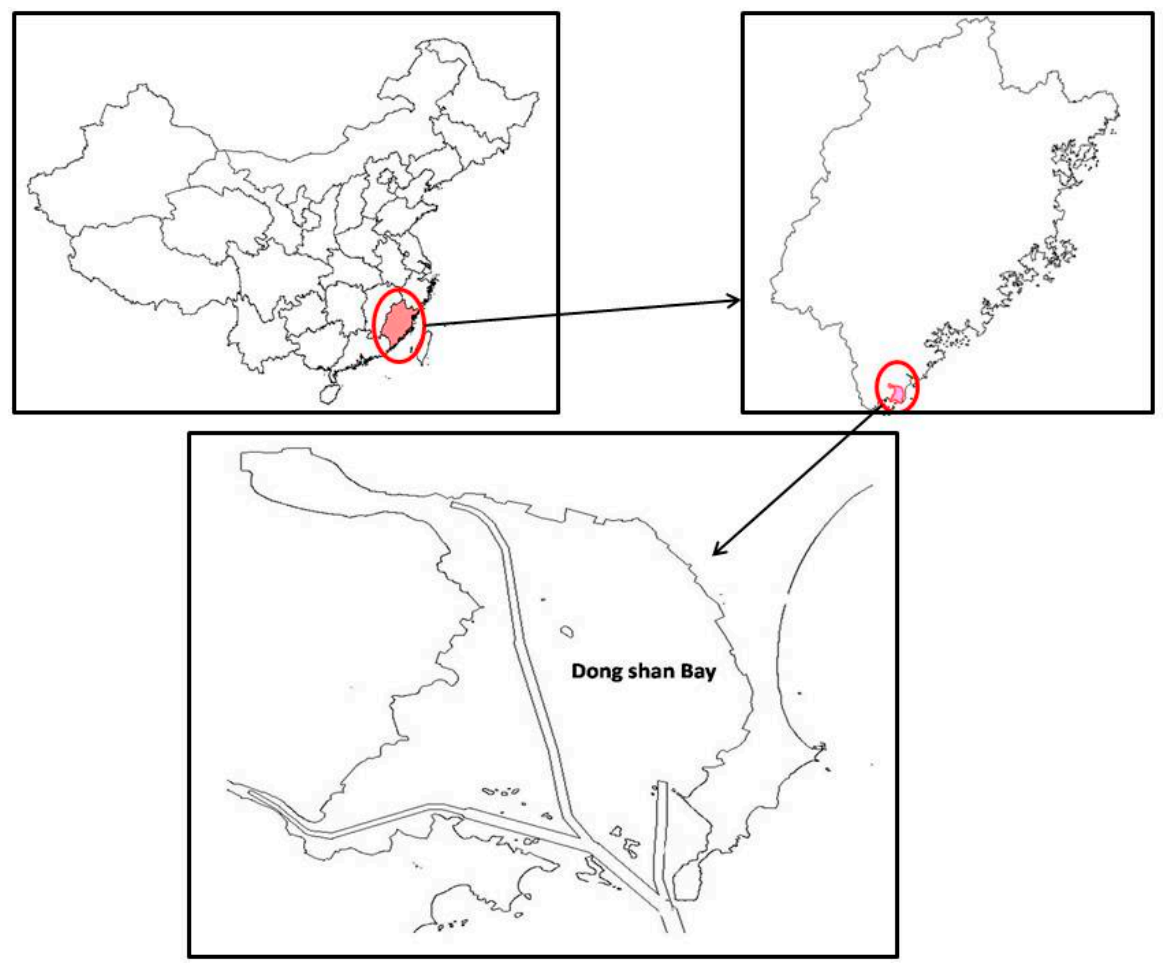

Figure 1. The location of Dongshan Bay in China's Fujian Province. 


\subsection{Construction of Index System}

Based on the constituent elements of vulnerability, a coastal ecological vulnerability index system under oil spill stress was constructed, and specific evaluation indicators were organized through the target layer-guideline layer-parameter layer (Table 1).

Table 1. Evaluation index system for coastal ecological vulnerability under oil spill stress.

\begin{tabular}{|c|c|c|c|c|}
\hline \multicolumn{2}{|c|}{ Target Layer } & $\begin{array}{c}\text { Guideline } \\
\text { Layer }\end{array}$ & Index Layer & Selected Index Layer \\
\hline \multirow{5}{*}{$\begin{array}{c}\text { A Stress } \\
\text { vulnerability }\end{array}$} & \multirow{5}{*}{$\begin{array}{c}\text { Structural } \\
\text { vulnerability }\end{array}$} & \multirow[b]{2}{*}{ B1 Sensitivity } & C1 Ecological value & $\begin{array}{l}\text { D1 Level of protected species } \\
\text { D2 Nature reserve rating }\end{array}$ \\
\hline & & & C2 Socio-economic value & $\begin{array}{l}\text { D3 Breeding industry } \\
\text { D4 Port operations } \\
\text { D5 Tourism recreation area } \\
\text { D6 Water intake }\end{array}$ \\
\hline & & \multirow[b]{2}{*}{$\begin{array}{l}\text { B2 Adaptive } \\
\text { capability }\end{array}$} & $\begin{array}{l}\text { C3 Policy intervention } \\
\text { capability }\end{array}$ & $\begin{array}{l}\text { D7 Traffic convenience } \\
\text { D8 Difficulty in cleaning }\end{array}$ \\
\hline & & & C4 Self-purification capacity & $\begin{array}{l}\text { D9 Slope } \\
\text { D10 Trend } \\
\text { D11 Wave direction and the } \\
\text { angle between the coast } \\
\text { D12 Bending }\end{array}$ \\
\hline & & B3 Exposure & $\begin{array}{l}\text { C5 Simulation of oil } \\
\text { dispersion }\end{array}$ & $\begin{array}{l}\text { D13 Simulated pollution } \\
\text { concentration in evaluation unit }\end{array}$ \\
\hline
\end{tabular}

\subsection{Division of Evaluation Unit}

To determine the relative extent of the vulnerability of the gulf area under oil spill stress, units were divided based on the functions of coasts and the different coastal ecological categories, where the coastline of each unit does not exceed $4 \mathrm{~km}$. According to the above classification method, the gulf was divided into 32 evaluation units.

\subsection{Index Assignment}

For the evaluation indexes determined by qualitative evaluation, the grading and assignment were determined based on previous grading standards [5-7,19,20]; the cluster analysis method was used for the quantitative evaluation indexes with regional characteristics according to the survey results of the evaluation zone to determine the grading scope and to assign all evaluation indexes. The grading standards and assigned values of various evaluation indexes are shown in Table 2.

\subsection{Determination of Index Weight}

The analytic hierarchy process (AHP) and Delphi method are more superior in terms of quantitative analysis and objective consistency. Thus, 15 experts were invited to score the relative importance of each 
index in this study, and the analytic hierarchy process was used to conduct a consistency analysis on the index scores to ultimately determine the index weight (shown in Table 2).

Table 2. Assignment standards and weights of evaluation index system for coastal vulnerability under oil spill stress.

\begin{tabular}{|c|c|c|c|c|c|c|c|}
\hline \multirow{2}{*}{$\begin{array}{l}\text { Target } \\
\text { Layer } 1\end{array}$} & \multirow{2}{*}{$\begin{array}{c}\text { Target } \\
\text { Layer } 2 \\
\end{array}$} & \multirow{2}{*}{$\begin{array}{l}\text { Index Layer } \\
\text { and Weight }\end{array}$} & \multicolumn{5}{|c|}{ Assignment Standard } \\
\hline & & & $\mathbf{0}$ & 1 & 3 & 5 & 7 \\
\hline \multirow{8}{*}{ 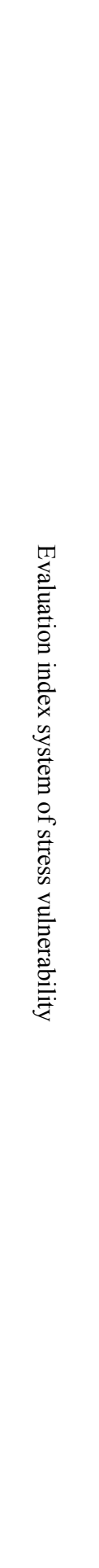 } & \multirow{8}{*}{ 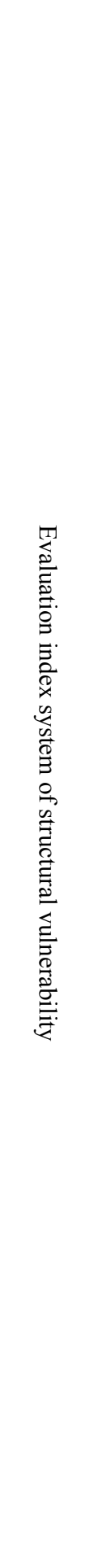 } & $\begin{array}{c}\text { D1 } \\
\text { Level of } \\
\text { protected } \\
\text { species } \\
(0.234375)\end{array}$ & $\begin{array}{c}\text { Non-protected } \\
\text { species }\end{array}$ & $\begin{array}{c}\text { Regional } \\
\text { protected } \\
\text { species }\end{array}$ & $\begin{array}{l}\text { Other national } \\
\text { and provincial } \\
\text { protected } \\
\text { species }\end{array}$ & $\begin{array}{l}\text { Second grade } \\
\text { state } \\
\text { protected } \\
\text { species }\end{array}$ & $\begin{array}{c}\text { First grade state } \\
\text { protected } \\
\text { species }\end{array}$ \\
\hline & & $\begin{array}{c}\mathrm{D} 2 \\
\text { Nature reserve } \\
\text { rating } \\
(0.078125) \\
\end{array}$ & $\begin{array}{c}\text { General } \\
\text { ecologically } \\
\text { sensitive areas }\end{array}$ & & $\begin{array}{c}\text { Important } \\
\text { ecologically } \\
\text { sensitive areas }\end{array}$ & & $\begin{array}{c}\text { Special } \\
\text { ecologically } \\
\text { sensitive areas }\end{array}$ \\
\hline & & $\begin{array}{c}\text { D3 } \\
\text { Breeding } \\
\text { industry(area } \\
\text { ratio) } \\
(0.046875) \\
\end{array}$ & $0-0.093$ & $0.094-0.190$ & $0.191-0.424$ & $0.425-0.521$ & $>0.521$ \\
\hline & & $\begin{array}{c}\text { D4 } \\
\text { Port } \\
\text { transportation } \\
(10000 \text { tons }) \\
(0.009375) \\
\end{array}$ & None & $1-1000$ & $1000-3000$ & $3000-6000$ & $>6000$ \\
\hline & & $\begin{array}{c}\text { D5 } \\
\text { Tourism } \\
\text { recreation area } \\
(0.046875)\end{array}$ & None & $\begin{array}{c}\text { Near-shore } \\
\text { historical and } \\
\text { cultural scenic } \\
\text { spot }\end{array}$ & $\begin{array}{l}\text { Waterfront } \\
\text { parks, } \\
\text { recreation beach }\end{array}$ & $\begin{array}{c}\text { Public } \\
\text { swimming } \\
\text { beach water } \\
\text { sports and } \\
\text { entertainment } \\
\text { area }\end{array}$ & \\
\hline & & $\begin{array}{c}\text { D6 } \\
\text { Water intake } \\
(0.084375)\end{array}$ & None & $\begin{array}{c}\text { General } \\
\text { industrial } \\
\text { water intake }\end{array}$ & $\begin{array}{l}\text { Aquaculture } \\
\text { water intake }\end{array}$ & $\begin{array}{c}\text { Cooling } \\
\text { water intake }\end{array}$ & $\begin{array}{c}\text { Drinking water } \\
\text { source intake }\end{array}$ \\
\hline & & $\begin{array}{c}\text { D7 } \\
\text { Traffic } \\
\text { convenience } \\
\text { (within } 1 \mathrm{~km} \text { ) } \\
(0.02955) \\
\end{array}$ & State Road & Highway & County road & $\begin{array}{c}\text { Township } \\
\text { road }\end{array}$ & Unreachable \\
\hline & & $\begin{array}{c}\text { D8 } \\
\text { Type of coast } \\
(0.08865)\end{array}$ & $\begin{array}{l}\text { Bedrock, } \\
\text { breakwater }\end{array}$ & $\begin{array}{c}\text { Rocks, } \\
\text { artificial } \\
\text { simple } \\
\text { revetment }\end{array}$ & $\begin{array}{c}\text { Sand, gravel } \\
\text { sediment }\end{array}$ & $\begin{array}{c}\text { Beach } \\
\text { sediment }\end{array}$ & $\begin{array}{l}\text { Wetlands, } \\
\text { mangroves }\end{array}$ \\
\hline
\end{tabular}


Table 2. Cont.

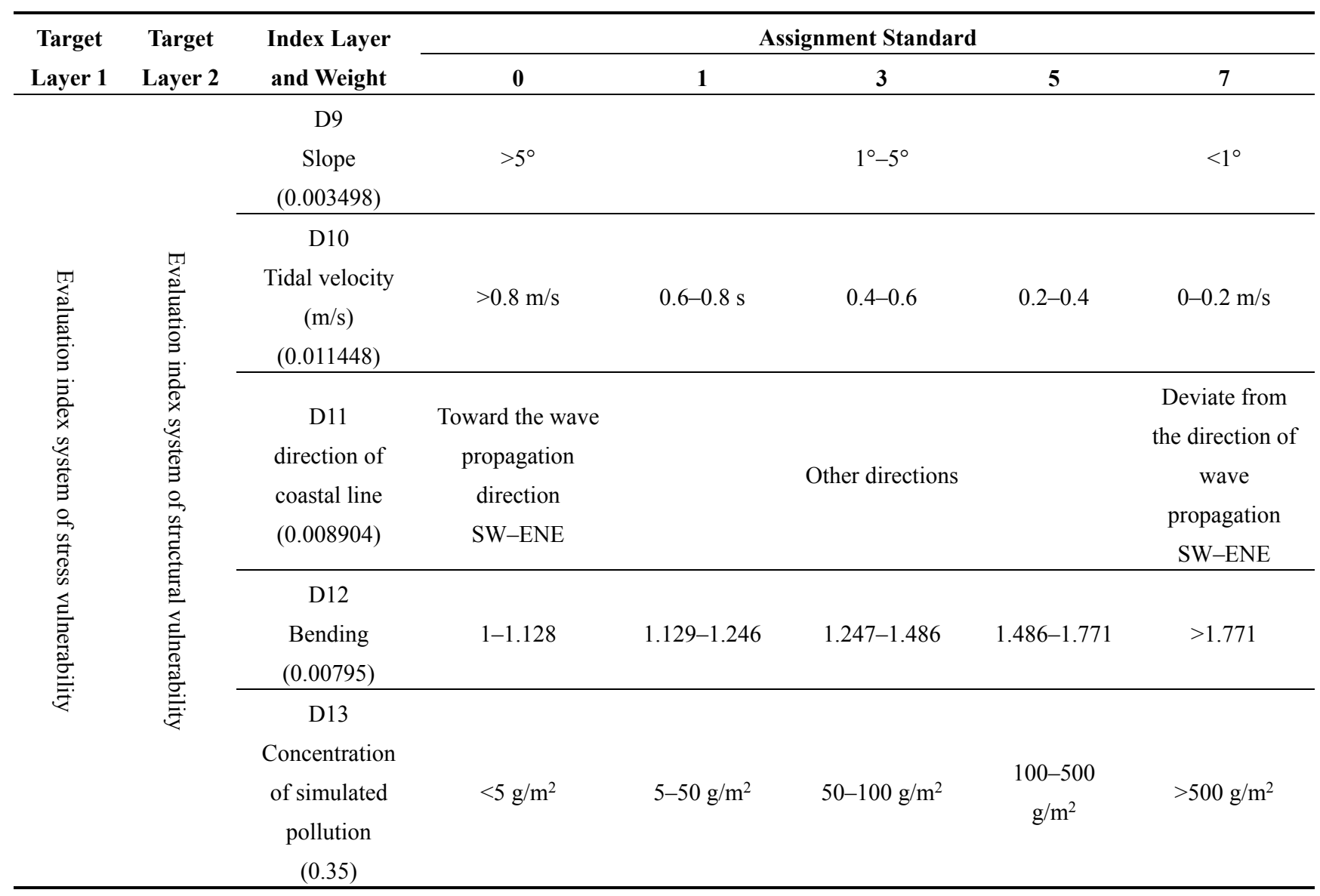

\subsection{Comprehensive Assessment of Ecological Vulnerability}

Vulnerability of a coast under oil spill stress is a relative concept that indicates the internal regional differences inside the evaluation system. Through standardization and value assignment of the evaluation indexes, the assignment grades of evaluation indexes in various types or values were determined, which were then multiplied by the weights. All evaluation indexes in each evaluation unit were superimposed as shown in Equation 1, and the vulnerability value ( $E V D)$ was determined:

$$
E V D=\sum_{i=1}^{n} p_{i} \cdot w_{i}
$$

where $E V D$ refers to the vulnerability of evaluations units, $n$ is the sum of all indexes in each layer, $p_{i}$ refers to the score of $i$ index, and $w_{i}$ is the weight of $i$ index in each index value.

\subsection{Oil Spill Simulation}

The statistical analysis of the International Tanker Owners Pollution Federation on the causes of oil spill-related accidents [21] reveals that small and medium accidents mainly occur in the ports and docks, most of which are operational oil spills, whereas 59\% of large-scale accidents, which are caused by collisions, allusions, and groundings. These same causes accounted for an even higher percentage of incidents when the vessel was underway in inland or restricted waters, being linked to some $99 \%$ of 
spills. Hence, the front area of operational wharfs and the channel cross were selected as the sites for this simulation (Figure 2). As the wharf is designed for 150,000 ton oil tankers, and a cabin can hold 8000 tons of oil, the amount of leakage was set as the maximum of a unilateral oil spill (8000 tons). The condensate of oil chosen for the maximum volume has a density of $740 \mathrm{~kg} / \mathrm{m}^{3}$ and tends to dissipate completely through evaporation within a few hours and does not normally form emulsions [1]. Case-selected leakage position trends and the direction of the wind in the most unfavorable combinations, which will have the largest impact in the selected gulf area as the oil spill situation, were established (Table 3).

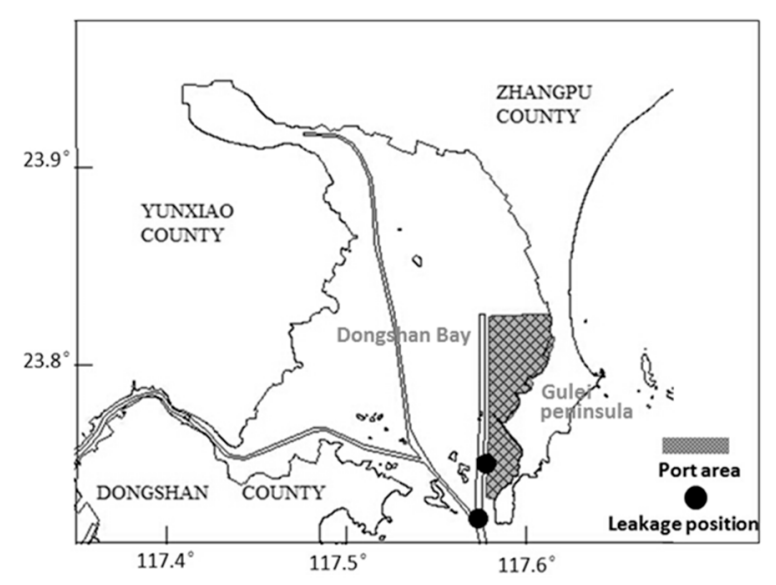

Figure 2. Leakage position of designed oil spill.

Table 3. Designed oil spill cases.

\begin{tabular}{ccccc}
\hline Case & $\begin{array}{c}\text { Leakage } \\
\text { Position }\end{array}$ & $\begin{array}{c}\text { Time of Leakage } \\
\text { Occurrence }\end{array}$ & $\begin{array}{c}\text { Duration of } \\
\text { Simulation }\end{array}$ & Wind \\
\hline 1 & $\begin{array}{c}\text { Front area of } \\
\text { the wharf } \\
\text { Front area of } \\
\text { the wharf }\end{array}$ & During high-tide & $12 \mathrm{~h}$ & $\begin{array}{c}\text { Perennial leading wind from NE direction } \\
\text { with average wind speed } 7.5 \mathrm{~m} / \mathrm{s}\end{array}$ \\
2 & $\begin{array}{c}\text { Front area of } \\
\text { the wharf }\end{array}$ & During low tide & $24 \mathrm{~h}$ & $\begin{array}{r}\text { Summer leading wind from SSE direction } \\
\text { with average wind speed } 3.1 \mathrm{~m} / \mathrm{s}\end{array}$ \\
4 & $\begin{array}{c}\text { Junction of } \\
\text { waterways }\end{array}$ & During low tide & $12 \mathrm{~h}$ & $\begin{array}{r}\text { S directional wind, and the maximum wind } \\
\text { speed allowed for operation is } 14 \mathrm{~m} / \mathrm{s} \\
\text { Summer leading wind from SSE direction }\end{array}$ \\
\hline
\end{tabular}

\section{Results}

\subsection{Oil Spill Simulation Results}

A three-dimensional MIKE 3 numerical model was used to calculate the oil trajectory. Apart from advection-dispersion, the model includes the reactive processes of emulsification, dissolution, evaporation, and heat exchange between the oil, the sea, and the atmosphere, which have been verified by Goran Loncar [22] in 2012, in that it reflects the oil spill's process at the sea to a certain extent. According to the designed oil spill cases in Table 2, the "MIKE model" was used to simulate the oil spill incident that occurred under the dispersion conditions. The specific pollutant concentration distribution is shown in Figure 3. 

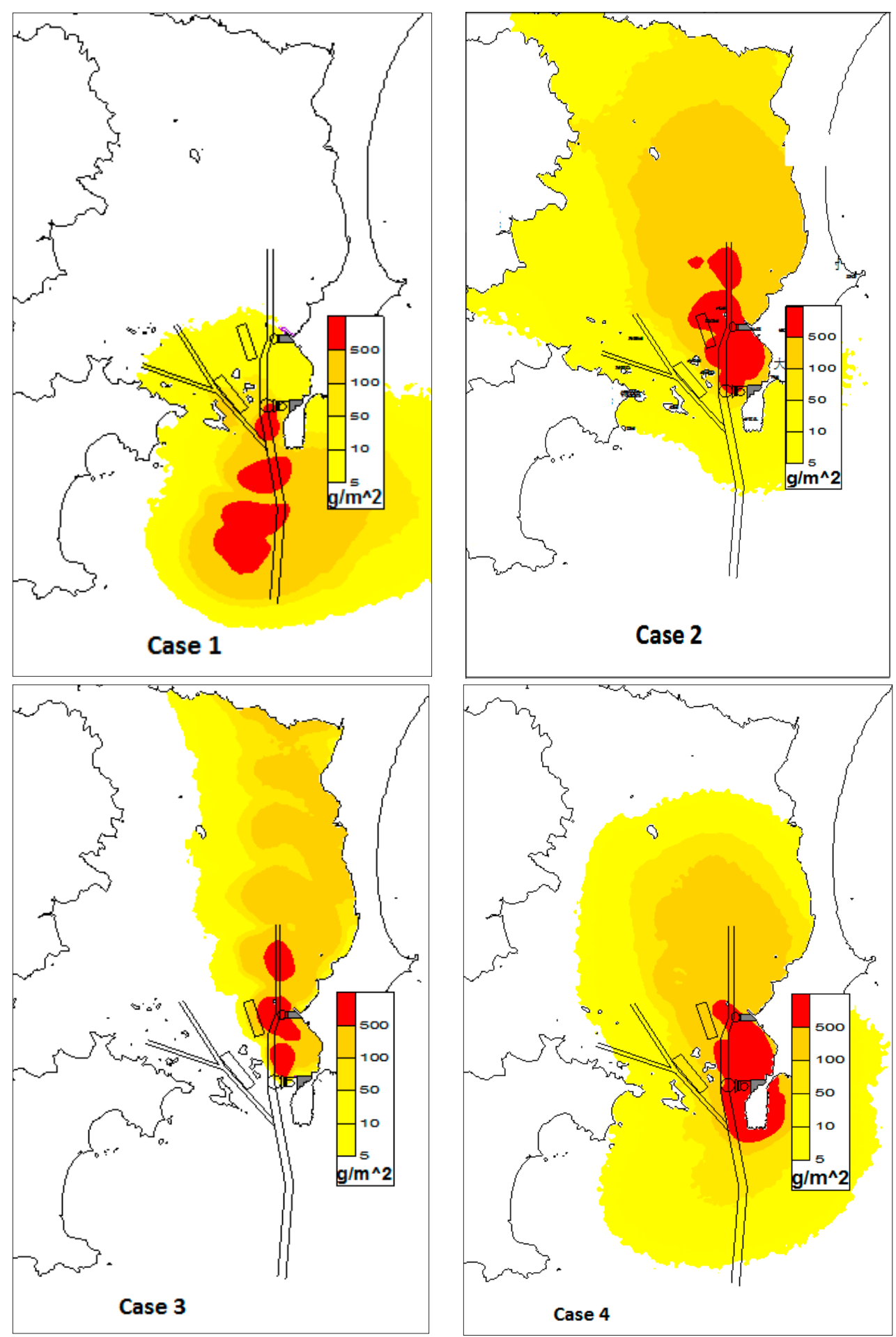

Figure 3. Simulation diagram of oil spill incident.

\subsection{Vulnerability Evaluation Results}

The coastal ecological vulnerability values of all evaluation units were calculated based on Equation (1). For the calculated ecological vulnerability indexes, the k-means clustering algorithm was adopted and the ecologically-vulnerable regions of the gulf were divided into five regions, namely nonvulnerable, slightly vulnerable, moderately-vulnerable, vulnerable, and extremely vulnerable regions. 
The dividing standards for the ecologically vulnerable regions are shown in Table 4. The divided evaluation results are shown in Figure 4.

Table 4. Criteria of ecologically vulnerable zones.

\begin{tabular}{cccccc}
\hline \multirow{2}{*}{ Categories } & \multicolumn{4}{c}{ Ecological Vulnerability Index } \\
\cline { 2 - 6 } & $\begin{array}{c}\text { Non-Vulnerable } \\
\text { Region }\end{array}$ & $\begin{array}{c}\text { Slightly } \\
\text { Vulnerable Region }\end{array}$ & $\begin{array}{c}\text { Moderately- } \\
\text { Vulnerable Region }\end{array}$ & $\begin{array}{c}\text { Vulnerable } \\
\text { Region }\end{array}$ & $\begin{array}{c}\text { Extremely } \\
\text { Vulnerable Region }\end{array}$ \\
\hline $\begin{array}{c}\text { Structural } \\
\text { vulnerability }\end{array}$ & $0-0.46$ & $0.46-1.00$ & $1.00-2.02$ & $2.02-3.07$ & $>3.07$ \\
\hline $\begin{array}{c}\text { Stress } \\
\text { vulnerability }\end{array}$ & $0-0.66$ & $0.66-1.22$ & $1.22-2.02$ & $2.02-3.07$ & $>3.07$ \\
\hline
\end{tabular}
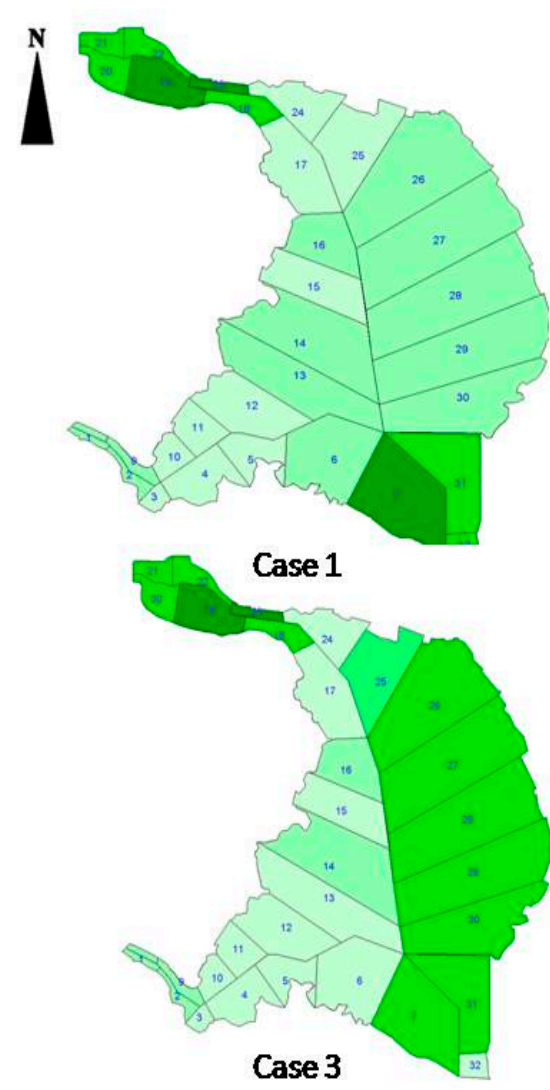

Case 3

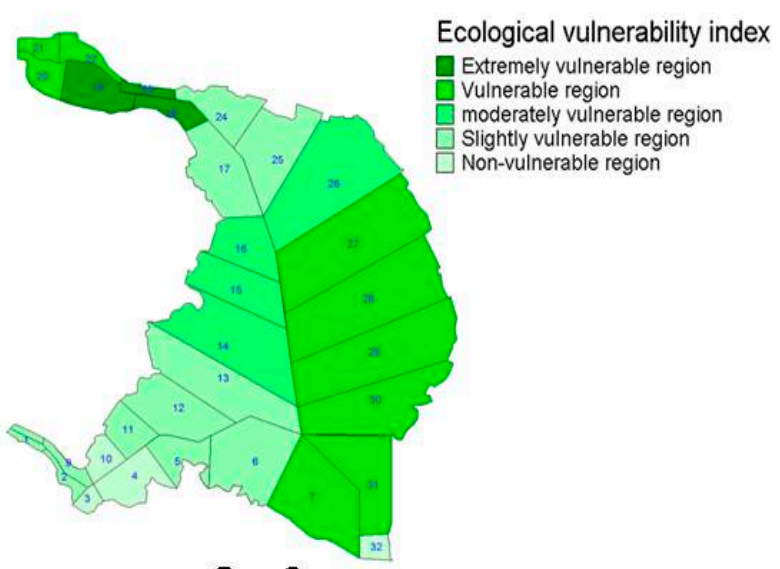

Case 2

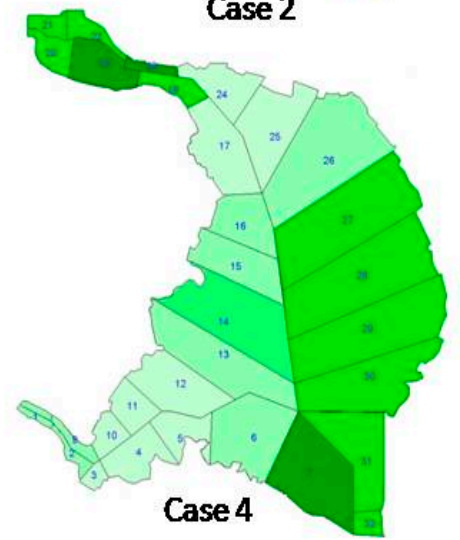

Figure 4. Distribution map of coastal vulnerability under oil spill stress.

Overall, most stress vulnerabilities belong to the vulnerable region, which are mainly distributed in the bay top and bay mount region in the east of the bay.

\section{Discussions}

In this study, the vulnerability of the coastal ecosystem under oil spill stress reflects a property of the coastal ecosystem that is exposed to the oil spill pollution. The structure and functions of the coastal ecosystem change easily because of its sensitivity to the oil pollution and the lack of the corresponding adaptive capability. The simulation results of the working conditions of different oil spill accidents show that the ecological vulnerability distribution of the coastal zone of Dongshan Bay is slightly different. 
Case 1 simulated the vulnerability distribution when the oil spill accidents happen at the front area of the wharf during high tide under the perennial leading wind in the NE direction. In this condition, the vulnerable region and the extremely vulnerable region are distributed at the evaluation units at the head and top of Dongshan Bay (Figure 3). Cases 2, 3, and 4 simulated the vulnerability distribution in the bay when oil spill accidents happen at the front area and the junction of waterways during low tide with the wind from the S and SSE directions. The simulation shows that, in addition to the top and head of the bay, the evaluation units close to the Gulei Peninsula belong to the area that is ecologically vulnerable.

Analysis shows that the evaluation result can be accounted for by the location of the Zhangjiangkou national mangrove forestry natural reserve at the top of Dongshan Bay. In this location, a large number of rare tree species and aquaculture are distributed; thus, the location has a high ecological value. In addition, both the hydrodynamic condition and the self-cleaning capability are poor at the top of the bay. Recovery from oil spill accidents is difficult. Thus, the ecosystem of this location is relatively vulnerable. Other vulnerable regions in the bay are mainly distributed at the head of the bay and in Gulei Peninsula to the east, which is related to the distribution of the coral protection regions and ecological breeding regions in these areas. As a result, the ecosystem of the region is highly sensitive. At the same time, oil transportation in Dongshan Bay is mainly concentrated at the operating area of the Gulei Port, near the head of the bay. This situation intensifies the risk for oil spill accidents. The perennial tides and wind direction affecting oil diffusion also contribute to the easy diffusion of oil toward the east sea of the Dongwan Bay. Comprehensive analysis shows that the evaluation result is basically consistent with the actual situation.

This paper is focused on ecological vulnerability assessment of coastal zones under an oil spill scenario, the coastal zone vulnerability indicators related to the oil spill under the duress of society, such as population density, quality of the population, age composition, etc., was not taken into account. At the same time, the weight of economic vulnerability indexes, such as aquaculture and scenic spots were considered relatively weak, but when an oil spill occurred, a good response strategy should integrate ecological vulnerability, social vulnerability, and economic vulnerability into consideration. Thus, in the future, research should consider, comprehensively, the ecological, social, and economic vulnerability of an oil spill to assess the distribution of the system, making the proposed contingency strategy more scientific and rational, and thus more valuable.

\section{Acknowledgments}

This work was supported by National Natural Science Foundation of China, Grant No. 41406121.

\section{Author Contributions}

Ling Cai and Jialin Ni designed this research and wrote the paper. Cui Wang performed the computer simulation work, Jialin Ni and Li Yan analyzed the data. All authors read and approved the final manuscript.

\section{Conflict of Interest}

The authors declare no conflict of interest. 


\section{References}

1. Van de Wiel, G.; van Drop, J.R. An oil outflow model for tanker collisions and groundings. Ann. Oper. Res. 2011, 187, 279-304.

2. Gundlach, E.R.; Hayes, M.O. Vulnerability of coastal environments to oil spill impacts. Mar. Technol. Soc. J. 1978, 12, 18-27.

3. Hanna, R.G.M. An approach to evaluate the application of the vulnerability index for oil spills in tropical Red Sea environments. Spill Sci. Technol. Bull. 1995, 2, 171-186.

4. Fisher, B.; Bellman, C.; Ellis, J. The development of a spatiotemporal environmental sensitivity index using GIS. Reef. Res. 1997, 7, 3-4.

5. Michel, J.; Hayes, M.O.; Dahlin, J.A.; Barton K. Sensitivity Mapping of Inland Areas: Technical Support to the Inland Area Planning Committee Working Group USEPA Region 5; Hazardous Response and Assessment Division of NOAA: Seattle, WA, USA, 1995.

6. Peterser, J.; Michel, J.; Zengel, S.; White, M.; Lord, C.; Plank, C. Environmental Sensitivity Index Guidelines, 3rd ed.; Hazardous Materials Response Division Office of Response and Restoration of NOAA: Seattle, WA, USA, 2002.

7. Wieczorek, A.; Dias-Brito, D.; Milanelli, J.C.C. Mapping oil spill environmental sensitivity in Cardoso Island State Park and surroundings areas, Sao Paulo, Brazil. Ocean Coast. Manag. 2007, $50,872-886$.

8. Castanedo, S.; Juanes, J.A.; Medina, R. Oil spill vulnerability assessment integrating physical, biological and socio-economical aspects: Application to the Cantabrian coast (Bay of Biscay, Spain). J. Environ. Manag. 2009, 91, 149-159.

9. Marília, M.; Andrade, N. A socioeconomic and natural vulnerability index for oil spills in an Amazonian harbor: A case study using GIS and remote sensing. J. Environ. Manag. 2011, 910, 1972-1980.

10. Singkran, N. Classifying risk zones by the impacts of oil spills in the coastal waters of Thailand. Mar. Pollut. Bull. 2013, 70, 34-43.

11. Vafai, F.; Hadipour, V. Determination of shoreline sensitivity to oil spills by use of GIS and fuzzy model. Case study at the coastal areas of Caspian Sea in north of Iran. Ocean Coast. Manag. 2013, 71, 123-130.

12. Alves, T.M.; Kokinou, E.; Zodiatis, G. A three-step model to assess shoreline and offshore susceptibility to oil spills: The South Aegean (Crete) as an analogue for confined marine Basins. Mar. Pollut. Bull. 2014, 86, 443-457.

13. Alves, T.M.; Kokinou, E.; Zodiatis, G. Modelling of oil spills in confined maritime basins: The casefor early response in the Eastern Mediterranean Sea. Environ. Pollut. 2015, 206, 390-399.

14. Tian, Y.; Xiang, Q.; Wang, P. Vulnerability of Regional Coupled Human-environment System of Its Evaluation Index System. Geogr. Res. 2013, 32, 55-63.

15. Adger, W.N. Vulnerability. Glob. Environ. Chang. 2006, 16, 268-281.

16. Turner, B.L., II; Kasperson, R.E.; Matson, P.A. A framework for vulnerability analysis in sustainability science. Proc. Natl. Acad. Sci. USA 2003, 100, 8074-8079.

17. Gallopin, G.C. Linkages between vulnerability, resilience, and adaptive capacity. Glob. Environ. Chang. Press 2006, 16, 293-303. 
18. Chen, P.; Chen, X. Summary on Research of Coupled Human-Environment System Vulnerability under Global Environmental Change. Prog. Geogr. 2010, 29, 454-462.

19. Romero, A.F.; Abessa, D.M.S.; Fontes, R.F.C.; Silva, G.H. Integrated assessment for establishing an oil environmental vulnerability map: Case study for the Santos Basin region, Brazil. Mar. Pollut. Bull. 2013, 74, 156-164.

20. Zavharias, M.; Gregrt, E.J. Sensitivity and vulnerability in marine environments: An approach to identifying vulnerability marine areas. Conserv. Biol. 2005, 19, 86-97.

21. Loncar, G.; Leder, N.; Paladin, M. Numerical modeling of an oil spill in the northern Adriatic. Ocenologia 2012, 54, 143-173.

22. Adler, E.; Inbar, M. Shoreline sensitivity to oil spills, the Mediterranean coast of Israel: Assessment and analysis. Ocean Coast. Manag. 2007, 50, 24-34.

(C) 2015 by the authors; licensee MDPI, Basel, Switzerland. This article is an open access article distributed under the terms and conditions of the Creative Commons Attribution license (http://creativecommons.org/licenses/by/4.0/). 